\title{
Effect of Attitude Mediating Subjective Norm, Perceived Behaviour Control, and Perceived Ease of Use on Online Purchase Intention Fashion Product Category
}

\author{
Dery Muhammad Yusuf and Zulfitri
}

\section{ABSTRACT}

This study aims to analyze the role of the Attitude variable in mediating Subjective Norm, Perceived Behavior Control, and Perceived Ease of Use on Online Purchase Intention for the fashion product category. The population of this study is people located in the Greater Jakarta area who have never shopped for fashion products online, with a total sample of 200 respondents. The data analysis method used Structural Equation Model-Partial Least Square (SEM-PLS). The results of the study found that Subjective Norm, Perceived Behavior Control, and Perceived Ease of Use had a positive and significant effect on Attitude. Attitude has a positive and significant effect on Online Purchase Intention of fashion products. Subjective Norm and Perceived Ease of Use have a positive and significant effect on Online Purchase Intention of fashion products. However, Perceived Behavior Control does not affect the Online Purchase Intention of fashion products. The implications of this research are discussed further in the article.

Keyword: Attitude, Fashion Products, Online Purchase Intention, Perceived Behavior Control, Perceived Ease of Use, Subjective Norm.
Submitted: October 08, 2021

Published: December 30, 2021

ISSN: 2507-1076

DOI: $10.24018 /$ ejbmr.2021.6.6.1135

Dery Muhammad Yusuf

Student, Postgraduate Faculty, Universitas

Mercu Buana Jakarta, Indonesia.

(e-mail: dery.my89@gmail.com) Zulfitri

Lecturer, Postgraduate Faculty, Universitas Mercu Buana Jakarta, Indonesia.

(e-mail: zulfitri@mercubuana.ac.id)

*Corresponding Author

\section{INTRODUCTION}

The rapid development of information technology brings a lot of influence on the activities or habits of the community. One of the sectors affected by advances in information technology is online shopping. From the many transactions in online shopping, according to statista.com, (2020) fashion products are the sector that has experienced a significant increase.

Based on the results of the pre-survey on 35 respondents, there are 5 statements with Yes answers above $85 \%$, namely the statements regarding subjective norms, perceived behavioral control, perceived ease of use and attitude.

\section{LITERATURE REVIEW}

\section{A. Online Purchase Intention}

Intention is defined as the part that motivates a behavior so that it characterizes how high a person's desire is to try (Ajzen \& Driver, 1991). In consumer intentions, purchase intention is an indicator that shows the consumer's desire to make purchases in the future (Morwitz et al., 2007).

In line with this, online purchase intention can be interpreted as consumer interaction with technology with the aim of transacting to buy the desired products and services (Heijden et al., 2003). Online purchase intention can be interpreted as the benefits that consumers get when using technology to find information or make a purchase (Pavlou et al., 2013).
Online purchase intention is measured based on several indicators such as the desire to buy through the website/online store, the desire to buy in the future (future intention), and transacting at the online store (transaction) (Peña-García $e t$ al., 2020).

\section{B. Attitude}

Attitude is defined as the tendency of a person to like or dislike an object or event (Rausch \& Kopplin, 2020). In the context of consumers, attitude is something that influences decision making because of its tendency towards a product or service (Wu, 2003).

Attitude towards a product will direct someone to make a purchase so that a strong attitude will increase an individual's confidence to make a purchase (Gunawan, 2015). Attitude can be measured through three indicators, namely affect which explains how consumers perceive the attitude towards the object. Then the behavior that refers to how the consumer acts on the object or in some cases is related to the intention to take action against the object. The last is cognition which is related to beliefs about things that are true from the object's attitude (Solomon, 2018).

\section{Subjective Norm}

Subjective Norm is defined as a person's perception of pressure in the social environment that is accepted so that it shows certain behavior through considerations made by someone (Ajzen, 2005). The social environment in question is an environment that is close to someone such as family, friends, colleagues at work and others. 
Inputs from social groups have an important and significant impact on the purchasing decisions of potential consumers. This is because information from each individual may be biased so that potential consumers will seek opinions from people, they trust such as family, friends, or coworkers (Aqila et al., 2016).

\section{Perceived Behavioral Control}

Perceived Behavioral Control is a person's belief in showing certain desired behavior. Perceived Behavioral Control is the belief to do or not do something. These beliefs can come from the past and can also be obtained from other people's information.

The construction of Perceived Behavioral Control must take advantage of the perception of the factors that support or hinder the performance of the behavior (Armitage \& Conner, 2001).

\section{E. Perceived Ease of Use}

Perceived ease of use is defined as the belief that a person feels in mastering a technology without any significant effort (Venkatesh \& Davis, 2000). This concept in online shopping can be interpreted as the ability to master an application or website without significant difficulty or effort (Gefen \& Straub, 2000).

Perceived ease of use is measured through indicators such as consumer ratings of ease of use, ease of learning, flexibility, and clarity of the user interface (Li et al., 2020).

\section{Methodology ReSEARCH}

Based on the background and theoretical study of several variables, the conceptual framework developed in this study can see in figure 1.

The population analyzed in this study is the Greater Jakarta Area community who have never shopped for fashion products through an online shop. The number of samples analyzed were 200 respondents. The analytical method used to answer the problem formulation in this study is structural equation modeling (SEM) through analysis of the outer model and inner model.

\section{RESULT}

\section{A. Descriptive Respondent Answer}

A total of 89 respondents or $45 \%$ of respondents were male, while as many as 111 other respondents or $55 \%$ of respondents were female. So, from the results of the questionnaire data, it can be seen that the majority are women.

Based on the age of the respondents, the majority in this study were dominated by those in the age range of 26 years to 35 years, as many as 94 respondents or $47 \%$. This age range is the productive age range or often referred to as the millennial generation. The term comes from millennials created by two American historians and writers, William Strauss, and Neil Howe in several of their books. The millennial generation relies more on technology in everyday life compared to other generations.

Based on the occupations of the respondents, the majority of those who filled out the questionnaire were those who worked as private employees with a total of 103 respondents or $52 \%$ of the total respondents. This result is in line with the results of the release of the Central Statistics Agency in May 2021, where based on the results of the population census it is known that the employment status in Indonesia is dominated by private employees/employees.

Based on monthly income, the respondents who filled out the questionnaire were those who had an income of Rp. $4,500,000-\mathrm{Rp} .6,000,000$ that is as many as 82 respondents or $41 \%$. This range of income figures is still in accordance with the average minimum wage for the Greater Jakarta Area province in 2021, which is a minimum of Rp. 4,390,000. Thus, a person in the Greater Jakarta Area Zul Fitri can meet the minimum daily needs if they have a minimum income of Rp. 4,390,000.

The majority of respondents who filled out the questionnaire had a budget for fashion needs in the range of Rp. 500,000 - Rp. 2,500,000 that is as many as 148 respondents or $74 \%$. The majority of respondents choose to fulfill their main basic needs and then shop for fashion products.

The majority of respondents who filled out the questionnaire had experience using the internet for more than six years, as many as 112 respondents or $56 \%$. If it is associated with the characteristics of the previous respondents, namely age and occupation, these results provide an overview of the appropriateness of safety in their productive age. The respondents, the majority of whom work as private employees, have a tendency to use internet technology in their daily activities.

The results of the data processing show that the results of the descriptive test on the subjective norm variable from four indicators and as many as 200 respondents found that the indicator with the statement "People around me will support me buying fashion products online" is the indicator that has the highest index with a mean of 3,660. and the standard deviation of 1.084. Meanwhile, the indicator with the statement "People who influence me think that buying fashion products online is better for me" has the lowest index value with a mean of 3.380 and a standard deviation of 1.084 . This indicates that the respondents have confidence that the decision to purchase fashion products online will be supported by the people around them, because this support is important and becomes an important factor in making decisions.

Based on the results of data processing, it shows that the results of descriptive tests on perceived behavior control variables from four indicators and as many as 200 respondents found that the indicator with the statement "I feel that I can buy fashion products online" is the indicator that has the highest index with a mean of 3.960 and a standard deviation. 1.072. Meanwhile, the indicator with the statement "I feel I can control myself when buying fashion products online" is the lowest indicator with a mean of 3.680 and a standard deviation of 1.138. This shows that respondents need to have confidence that they are able to shop for fashion products online before making a purchase decision. 


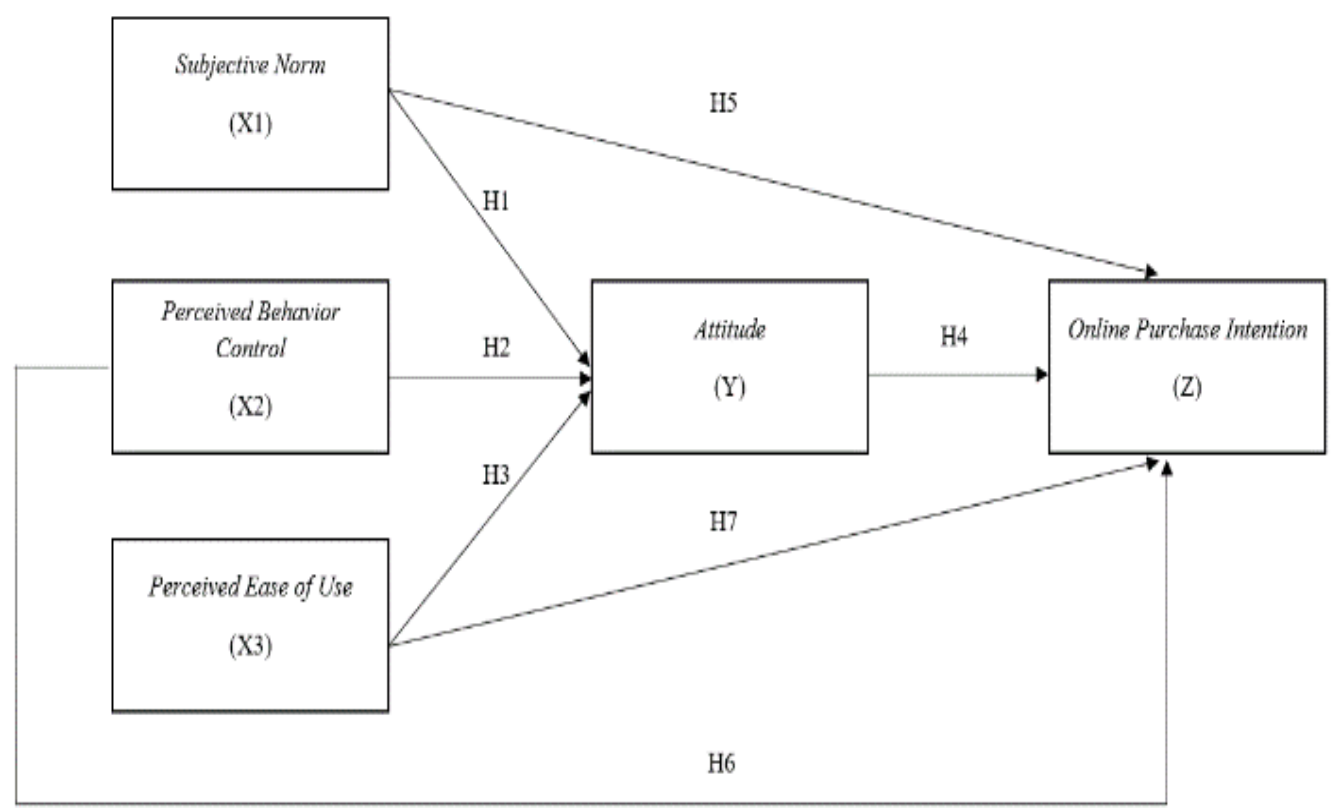

Fig. 1. Framework.

From the results of data processing, it shows that the results of descriptive tests on the perceived ease of use variable from four indicators and as many as 200 respondents found that the indicator with the statement "I feel buying fashion products online is easy" becomes the indicator that has the highest index with a mean of 3,900 and a standard deviation 1.187. Meanwhile, the indicator with the statement "I feel that the appearance of fashion products online is clearer" has the lowest index with a mean of 3.435 and a standard deviation of 1.302. These results show that in growing interest in purchasing fashion products online, the respondents consider the ease of using technology as the most decisive factor.

Based on the results of data processing shows that the results of descriptive tests on the perceived ease of use variable from four indicators and as many as 200 respondents it was found that the indicator with the statement "I feel buying fashion products online is fun" is the indicator that has the highest index with a mean of 3.865 and a standard deviation 1.173. Meanwhile, the indicator with the statement "I believe shopping for fashion products online has a positive impact on me" has the lowest total index value with a mean of 3.515 and a standard deviation of 1.192 . These results indicate that feeling happy will affect the attitude of respondents in responding to the interest in purchasing fashion products online.

Based on the results of data processing shows that the results of the descriptive test on the online purchase intention variable from six indicators and as many as 200 respondents it was found that the indicator with the statement "If there is an opportunity, I will buy fashion products online" is the indicator that has the highest index value with a mean of 3.915 and 1,062. Meanwhile, the indicator with the statement "I often plan to buy fashion products online" has the lowest total index value with a mean of 3.595 and a standard deviation of 1.049. This indicates that the majority of respondents always consider purchasing fashion products online and the purchase decision will be made when there is a suitable opportunity

\section{B. Hypothesis Result Testing}

The results of hypothesis testing are interpreted through the bootstrapping method by comparing T-Statistics with $\mathrm{T}$ Tables.

\begin{tabular}{cccc}
\multicolumn{4}{c}{ TABLE I: HYPOTESIS RESULT } \\
\hline & $\begin{array}{c}\text { Original } \\
\text { Sample }(\mathrm{O})\end{array}$ & $\begin{array}{c}\text { T Statistics } \\
(\mid \text { O/STDEV })\end{array}$ & P-Values \\
\hline Attitude -> OPI & 0.461 & 4.968 & 0.000 \\
PBC -> Attitude & 0.250 & 3.316 & 0.001 \\
PBC -> OPI & -0.053 & 0.990 & 0.322 \\
PEOU -> Attitude & 0.268 & 3.194 & 0.001 \\
PEOU -> OPI & 0.321 & 4.147 & 0.000 \\
SN - > Attitude & 0.360 & 5.343 & 0.000 \\
SN -> OPI & 0.216 & 3.447 & 0.001 \\
\hline
\end{tabular}

1) Based on the hypothesis test in this study, the results of the T-statistic value of 5.443 and the original sample value of 0.360 were obtained. The T-statistic value is more than the T-table value of 1.96 and the original sample value shows a positive value, this result shows that the subjective norm has a positive and significant effect on attitude.

2) Based on the hypothesis test in this study, the T-statistic value was 2.950 and the original sample value was 0.250 . The T-statistic value is more than the T-table value of 1.96 and the original sample value shows a positive value, this result shows that perceived behavior control has a positive and significant effect on attitude.

3) Based on the hypothesis test in this study, the results of the T-statistic value of 3.103 and the original sample value of 0.268 were obtained. The T-statistic value is more than the T-table value of 1.96 and the original sample value shows a positive value, these results indicate that perceived ease of use has a positive and significant effect on attitude.

4) Based on the hypothesis test in this study, the results of the T-statistic value of 5.044 and the original sample value of 0.461 were obtained. The T-statistic value is more than the T-table value of 1.96 and the original sample value shows a positive value, these results indicate that attitude has a positive and significant effect on online purchase intention. 


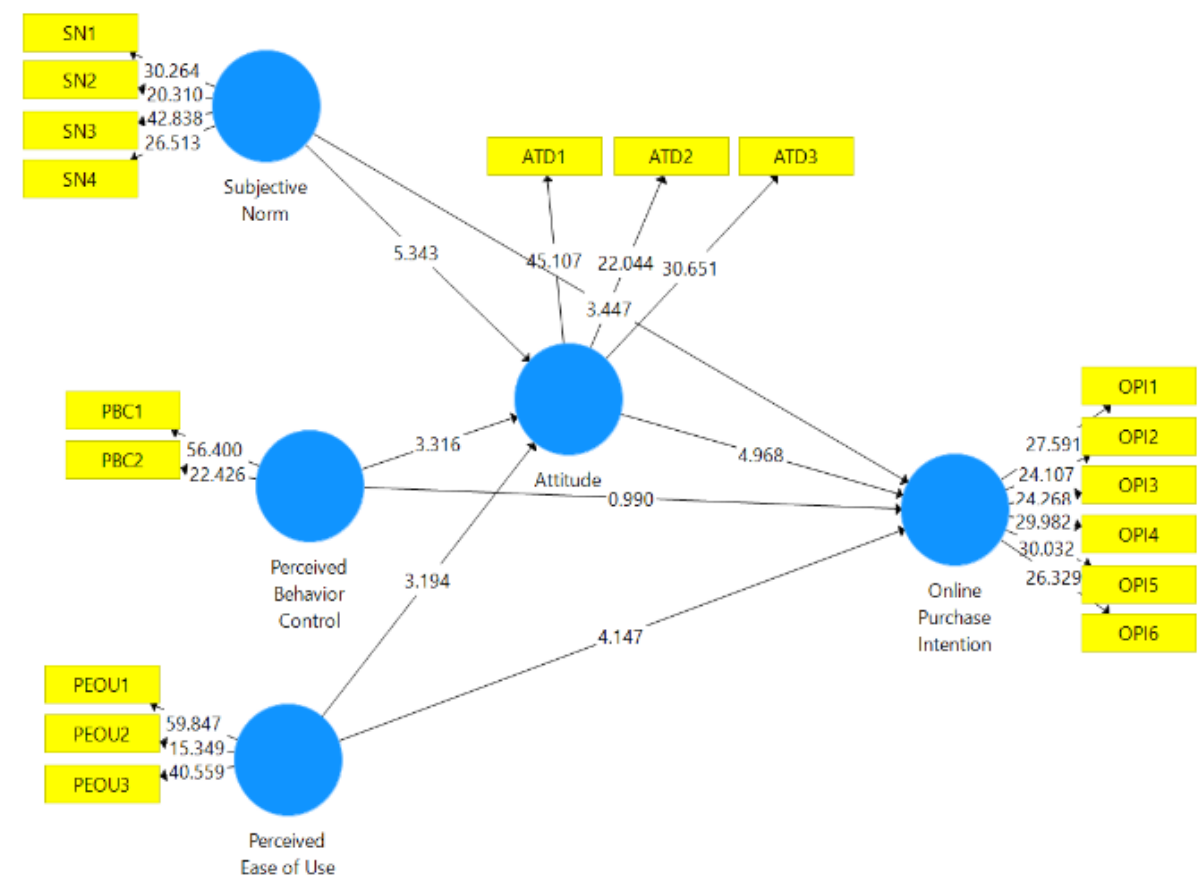

5) Based on the hypothesis test in this study, the T-statistic value was 3.218 and the original sample value was 0.216 . The T-statistic value is more than the T-table value of 1.96 and the original sample value shows a positive value, this result shows that usage interest has a positive and significant effect on online purchase intention.

1)

6) Based on the hypothesis test in this study, the T-statistics value was 1.021 and the original sample value was -0.053 . The T-statistic value is more than the T-table value of 1.96 and the original sample value shows a negative value, this result indicates that perceived behavioral control has a negative and significant effect on online purchase intention.

7) Based on the hypothesis test in this study, the T-statistics value was 3.965 and the original sample value was 0.321 . The T-statistic value is more than the T-table value of 1.96 and the original sample value shows a negative value, these results indicate that perceived ease of use has a positive and significant effect on online purchase intention.

8) Based on the hypothesis test in this study, the results in the table show that the three variables have a T-statistic value above 1.96 and the original sample value has a positive number. So that Attitude has a positive and significant indirect effect on the relationship between Subjective Norm, Perceived Behavior Control, and Perceived Ease of Use on Online Purchase Intention.

\section{DISCUSSION}

\section{A. Effect of Subjective Norm on Attitude}

Through the results of the study, it is indicated that the information obtained from people who are trusted by the respondent affects the attitude of the respondent so that it can encourage the interest of the respondents to shop for fashion products online. The findings in this study are supported by previous research that Subjective Norm has a significant effect on Attitude (Nam et al., 2017), (Matikiti, 2015).

\section{B. Effect of Perceived Behavior Control on Attitude}

Through the results of the study, it can be indicated that the respondents' views in responding to changes in behavior towards new habits have an impact on the attitudes of the respondents, especially in growing interest in shopping for fashion products online. The findings in this study are supported by previous research that Perceived Behavioral Control has a positive impact on attitude (Koththagoda \& Herath, 2018).

\section{The Effect of Perceived Ease of Use on Attitude}

Through the results of the study, it is indicated that the respondent's perception of the ease of use of a technology will affect his attitude, especially in internet-based technology used in online transactions when shopping for fashion. The results of this study are supported by previous research that the Perceived Ease of Use has a positive impact on attitude (Udayana \& Ramadhan, 2019).

\section{Effect of Attitude on Online Purchase Intention}

Through hypothesis testing, it is indicated that the attitude of the respondents affects the interest in shopping for fashion products online, this is because the respondents as consumers want something good and fun through online fashion product transactions. This is supported by previous research (Chiu et al., 2018).

\section{E. Effect of Subjective Norm on Online Purchase Intention}

Through testing, it is known that the higher the influence a person gets from the people he trusts, the higher the interest in online shopping grows in this case related to fashion products. The results of this study are supported by previous studies (Thi et al., 2019).

\section{F. Effect Perceived Behavior Control on Online Purchase Intention}

Through testing, it was found that respondents reacted negatively to the view of their behavioral control abilities when they wanted to transact online fashion products. This indicates that when respondents as consumers do not have 
control over their behavior, this will reduce their interest in buying fashion products online. The results of this study are supported by previous research that perceived behavior control has a negative impact on online purchase intention (Vinzi et al., 2011).

\section{G. Effect of Perceived Ease of Use on Online Purchase Intention}

Through test factor in growing interest in transacting fashion products online. This supports previous research that perceived ease of use has a positive impact on online purchase intention (Won \& Kim, 2020).

\section{H. Indirect Effect of Perceived Behavior Control on Online Purchase Intention toward Attitude}

If we compared the results of the Perceived Behavioral Control hypothesis test on Online Purchase Intention directly, through testing, it found that The Attitude variable has an indirect effect of Perceived Behavior Control on Online Purchase Intention. Thus, the perception of attitudes can reveal consumer buying interest even though they have a negative perception of behavioral control when shopping for fashion products online.

\section{CONCLUSION}

Based on the findings in this study, it can be concluded that subjective norms, perceived behavior control and perceived ease of use have a significant impact on increasing consumer attitudes. The attitude, subjective norm, and perceived ease of use have a positive impact on online purchase intention. In contrast to perceived behavior control which has a negative impact on online purchase intention.

It is hoped that further researchers can consider indicator instruments and questionnaire statements to be tested so that research results become better and more accurate and use other variables that have not been accommodated. So that this research becomes more comprehensive and sustainable. Suggestions for companies to consider these factors to attract consumer buying interest, especially the online fashion product category.

\section{REFERENCES}

Ajzen, I. (2005). Attitudes, Personality, and Behavior (T. Manstead (ed.); 2nd ed.). McGraw-Hill Education.

Ajzen, I., \& Driver, B. L. (1991). Prediction of leisure participation from behavioral, normative, and control beliefs: An application of the theory of planned behavior. Leisure Sciences, 13(3), 185-204. https://doi.org/10.1080/01490409109513137.

Aqila, N., Osman, A., Abdullah, S., \& Nizam, S. (2016). The Relationship of Attitude, Subjective Norm and Website Usability on Consumer Intention to Purchase Online: An Evidence of Malaysian Youth *. Procedia Economics and Finance, 35(October 2015), 493-502. https://doi.org/10.1016/S2212-5671(16)00061-7.

Armitage, C. J., \& Conner, M. (2001). E Y cacy of the Theory of Planned Behaviour: A meta-analytic review. 471-499.

Chiu, W., Kim, T., \& Won, D. (2018). Predicting consumers' intention to purchase sporting goods online: An application of the model of goaldirected behavior. Asia Pacific Journal of Marketing and Logistics, 30(2), 333-351. https://doi.org/10.1108/APJML-02-2017-0028.

Gefen, D., \& Straub, D. (2000). The Relative Importance of Perceived Ease of Use in IS Adoption: A Study of E-Commerce Adoption. October. https://doi.org/10.17705/1jais.00008.

Gunawan, S. (2015). The Impact of Motivation, Perception and Attitude toward Consumer Purchasing Decision: A Study Case of Surabaya and Jakarta Society on Carl 's Junior. 3(2), 154-163.

Heijden, H. Van Der, Verhagen, T., \& Creemers, M. (2003). Understanding online purchase intentions : contributions from technology and trust perspectives. July 2000, 41-48. https://doi.org/10.1057/palgrave.ejis.3000445.

Koththagoda, K. C., \& Herath, H. M. R. . (2018). Factors Influencing Online Purchasing Intention: The Mediation Role of Consumer Attitude. Journal of Marketing and Consumer Research, 42(2003), 66-74. www.ij\% 5Ciste.org.

Li, X., Zhao, X., Xu, W. (Ato), \& Pu, W. (2020). Measuring ease of use of mobile applications in e-commerce retailing from the perspective of consumer online shopping behaviour patterns. Journal of Retailing and

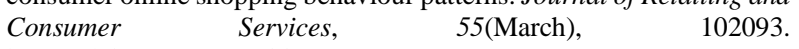
https://doi.org/10.1016/j.jretconser.2020.102093.

Matikiti, R. (2015). Social media in tourism: Establishing factors influencing attitudes towards the usage of social networking sites for trip organisation Theoretical background. 1-13.

Morwitz, V. G., Steckel, J. H., \& Gupta, A. (2007). When do purchase intentions predict sales? 23, 347-364. https://doi.org/10.1016/j.ijforecast.2007.05.015.

Nam, C., Dong, H., \& Lee, Y. A. (2017). Factors influencing consumers' purchase intention of green sportswear. Fashion and Textiles, 4(1). https://doi.org/10.1186/s40691-017-0091-3.

Pavlou, P. A., Fygenson, M., Pavlou, P. A., \& Fygenson, M. (2013). Understanding and Predicting Electronic Commerce Adoption: An Extension of the Theory of Planned Behavior Qjarteny and Predicting Understanding Electronic An Extension of Commerce Adoption: the Theory of Planned formed. 30(1), 115-143.

Peña-García, N., Gil-Saura, I., Rodríguez-Orejuela, A., \& Siqueira-Junior, J. R. (2020). Purchase intention and purchase behavior online: A crosscultural approach. Heliyon, 6(6). https://doi.org/10.1016/j.heliyon.2020.e04284.

Rausch, T. M., \& Kopplin, C. S. (2020). Bridge the gap: Consumers , purchase intention and behavior regarding sustainable clothing. $\begin{array}{llll}\text { Journal of Cleaner Production, 278, } 123882 . & .\end{array}$ https://doi.org/10.1016/j.jclepro.2020.123882.

Solomon, M. (2018). Consumer Behaviour : Buying, Having, and Being (S. Wall (ed.); 12th Editi). Pearson. https://www.pearson.com/us/highereducation/product/Solomon-Consumer-Behavior-Buying-Having-andBeing-12th-Edition/9780134129938.html.

Statista.com. (2020). Fashion Digital Market Outlook: Indonesia 2020. https://www.statista.com/outlook/244/120/fashion/indonesia

Thi, M., Nguyen, T., Nguyen, L. H., \& Nguyen, H. V. (2019). Materialistic values and green apparel purchase intention among young Vietnamese consumers. 20(4), 246-263. https://doi.org/10.1108/YC-10-20180859 .

Udayana, I., \& Ramadhan, D. (2019). Pengaruh perceived usefullness, perceived ease of use, dan subjective norm terhadap purchase intention melalui attitude sebagai mediasi (studi kasus pada konsumen gudang digital online Yogyakarta). Jurnal EBBANK, 10(2), 41-48. https://doi.org/2442-4439.

Venkatesh, V., \& Davis, F. D. (2000). A Theoretical Extension of the Technology Acceptance Model: Four Longitudinal Field Studies. Management Science, 46 (2) (May 2014), 186-204. https://doi.org/http://dx.doi.org/10.1287/mnsc.46.2.186.11926 Full.

Vinzi, V. E., Chin, W. W., Henseler, J., \& Wang, H. (2011). Springer Handbooks of Computational Statistics Series Editors. In J. E. Gentle, W. K. Hardle, \& Y. Mori (Eds.), Springer. https://doi.org/10.1007/9783-642-16345-6.

Won, J., \& Kim, B. Y. (2020). The effect of consumer motivations on purchase intention of online fashion-sharing platform. Journal of Asian Finance, Economics and Business, 7(6), 197-207. https://doi.org/10.13106/JAFEB.2020.VOL7.NO6.197.

$\mathrm{Wu}$, S. I. (2003). The relationship between consumer characteristics and attitude toward online shopping. Marketing Intelligence \& Planning, 21(1), 37-44. https://doi.org/10.1108/02634500310458135. 